\title{
AGONISTS OF CB1 AND NMDA RECEPTORS DECREASE THE TOXIC EFFECT OF ORGANOPHOSPHORUS COMPOUND PARAOXON ON PC12 CELLS
}

\author{
F. SALEM ${ }^{1}$, F. BAHRAMI,2®, Z. BAHARI', \\ Z. JANGRAVI ${ }^{3}$, S. NAJAFIZADEH-SARI ${ }^{4}$ \\ ${ }^{1}$ Neuroscience Research Center, Baqiyatallah University of Medical Sciences, Tehran, Iran; \\ ${ }^{2}$ Department of Physiology and Medical Physics, Faculty of Medicine, \\ Baqiyatallah University of Medical Sciences, Tehran, Iran; \\ ${ }^{3}$ Departmentof Biochemistry, Faculty of Medicine, Baqiyatallah University \\ of Medical Sciences, Tehran, Iran; \\ ${ }^{4}$ Student' Research Committee (SRC), Baqiyatallah University of Medical Sciences, Tehran, Iran; \\ 凶e-mail: f.bahrami@bmsu.ac.irorfarideh_bahrami@yahoo.com
}

Received: 01 July 2019; Accepted: 13 August 2019

Pharmacological studies allow to suggest that activation of cannabinoid type 1 receptors (CB1) have a neuroprotective role against toxicity induced by organophosphate agents, but the exact mechanisms of this effect as well as interaction with receptors of other types are far from clear. Therefore, the aim of current study was to evaluate the effect of CBI and NMDA receptors agonists on cell viability and biomarkers of oxidative stress and lipid peroxidation in PC12 cells exposed to paraoxon. PC12 cells were exposed to $100 \mu$ M paraoxon as organophosphate agent. Treatments with $1 \mu$ M arachidonyl-2'-chloroethylamide (ACEA) as specific agonist of CB1 receptors, $100 \mu M N$-methyl-D-aspartate (NMDA) as agonist of NMDA receptors and $1 \mu$ M AM251 as antagonist of CB1 receptors were done. Cell viability and biomarkers of oxidative stress were evaluated after $48 \mathrm{~h}$ of incubation. The level of CB1 receptor protein was evaluated by Western blotting. It was demonstrated that PC12 cells treatment with paraoxon led to cell viability inhibition, glutathione level, superoxide dismutase and catalase activity reduction, lipid peroxidation intensification and CBI receptor expression attenuation. Application of ACEA and NMDA was shown to be followed by normalization of these indices. The protective effect of ACEA was abolished when the CB1 receptors antagonist AM251 was applied. The study revealed that application of ACEA and NMDA can protect PC12 cells against paraoxon induced toxicity through antioxidant capacity increment, lipid peroxidation inhibition and enhanced expression of CB1 receptors.

Keywords: CB1 receptors, arachidonyl-2'-chloroethylamide, cannabinoid, $N$-methyl-D-aspartate, paraoxon, PC12 cells, oxidative stress.

$\mathrm{E}$ ndocannabinoids are widespread throughout the brain and its cannabinoid type 1 receptors (CB1) play an important neuro-modulatory role in the different brain areas [1]. The changes in CB1 receptor expression in response to injury and their role in neurogenesis suggest that $\mathrm{CB} 1$ receptors can mediate neuroprotective or neuroregenerative responses [2]. Numerous experimental studies indicate endocannabinoid system involvement in neural cells survival and protection from brain injury
[3-6]. It was shown that CB1 receptor expression is altered at various neurodegenerative diseases [7-11]. The results of pharmacological studies regarding the neuroprotective role of CB1 receptors in the brain have been controversial. For example, Iuvone et al. showed that application of cannabidiol has a neuroprotective and anti-apoptotic effects on $\beta$-amyloid peptide-induced toxicity in cultured rat pheocromocytoma PC12 cells [12]. On the contrary, some behavioral studies showed that application of cannabi-

(C) 2019 Salem F. et al. This is an open-access article distributed under the terms of the Creative Commons Attribution License, which permits unrestricted use, distribution, and reproduction in any medium, provided the original author and source are credited. 
noid agonists D9-THC and WIN 55,212-2 decreases cell proliferation and increases cell death of human GBM (glioblastoma multiforme) cells [13]. The existing data reveal that the rat pheochromocytoma, PC12 cell line is a useful model for neuroprotection studies $[14,15]$. Several pharmacological documents demonstrated the functional interaction between the CB1 and the N-methyl-D-aspartate (NMDA) receptors $[16,17]$. CB1 receptors are co-localized with NMDA receptors [18] in the post-synapse at both the spinal cord [19] and supraspinal levels [20, 21]. However, the exact mechanisms of their action are far from clear.

The NMDA receptor is critical for many developmental processes, including neuronal proliferation $[22,23]$. Wu et al. (2005) showed that the activation of NMDA receptors leads to protection against paraoxon-induced neurotoxicity and apoptosis in cultured cerebellar granule cells. Furthermore, these researchers demonstrated that the application of MK-801 (NMDA receptor antagonist) increased paraoxon-induced neurotoxicity and apoptosis [24]. Several studies demonstrated that NMDA receptors also regulate developmental neuronal damage $[25,26]$. Therefore, the activity of NMDA receptors is important to maintain the survival of neurons exposed to paraoxon. Organophosphates such as paraoxon are toxic substances that cause adverse effects on human and animals [27] and their use is still a constant threat to the population. Several studies have shown that organophosphates may induce production of reactive oxygen species and oxidative stress $[28,29]$. Therefore, the present study was designed to examine the effect of arachidonyl2'-chloroethylamide (ACEA) as a CB1 cannabinoid receptor agonist and N-methyl-D-aspartate (NMDA) as a NMDA receptor agonist on PC12 cells viability and the biomarkers of oxidative stress including malondialdehyde (MDA) content, glutathione (GSH) level and superoxide dismutase (SOD) and catalase (CAT) activities under the action of organophosphorus compound paraoxon.

\section{Material and Methods}

Cell Culture. PC12 cell line was purchased from Pasteur Institute (Tehran, Iran) and continuously grown in DMEM (Gibco, Eggnestein, Germany) culture medium supplemented with $10 \%$ fetal bovine serum (Gibco), $50 \mathrm{ng} / \mathrm{ml} \mathrm{NGF}$ (Sigma), 2 mM L-glutamine (Sigma-Aldrich, St. Louis, MO), $100 \mu \mathrm{g} / \mathrm{ml}$ penicillin, and $100 \mu \mathrm{g} / \mathrm{ml}$ streptomycin.
Cultures were maintained in a humidified incubator at $37{ }^{\circ} \mathrm{C}$ and $5 \% \mathrm{CO}_{2}$. The cells were seeded at a density of $0.75 \times 10^{5}$ cells $/ \mathrm{ml}$ in 6 -well culture dishes for enzyme or western blot assays and in 96-well dishes for viability measurement. The culture medium was changed every 2 days until the cells were confluent [30].

Experimental design. The culture dishes were seeded with equal number of cells $\left(0.75 \times 10^{5}\right.$ cells/ $\mathrm{ml})$ and after $48 \mathrm{~h}$ the cells were divided into two groups: the control and $100 \mu \mathrm{M}$ paraoxon (POX) treated. The paraoxon treated group was divided into the following groups: paraoxon alone; paraoxon and $1 \mu \mathrm{M}$ ACEA, paraoxon and $100 \mu \mathrm{M}$ NMDA; paraoxon and ACEA plus NMDA combination. In the last group the CB1 receptors antagonist $1 \mu \mathrm{M}$ AM251 was added before exposure to ACEA. All treatments were prolonged for $48 \mathrm{~h}$ at $37^{\circ} \mathrm{C}$.

Cell viability assay. Cell viability was estimated using the Cell Titre 96 Aqueous One Solution (MTS) Cell Proliferation Assay Kit (Promega Ltd.). PC12 Cells were seeded in 96-well plates at a density of $10^{4}$ cell per well in $200 \mu \mathrm{l}$ medium and allowed to adhere for $24 \mathrm{~h}$ at $37^{\circ} \mathrm{C}$. Then the medium was replaced with a fresh medium, the studied compounds were added as described above, the cells were incubated for $48 \mathrm{~h}$ at $37^{\circ} \mathrm{C}$ and washed with phosphate buffer saline (PBS). Then, $100 \mu 1$ of the serum-free culture medium containing $20 \mu \mathrm{l}$ of mixture of MTS [3-(4,5-dimethylthiazol-2yl)-5-(3carboxymethoxyphenyl)-2(4-sulfophenyl)-2H-tetrazolium] and PMS [phenazinemethosulfate as the electron coupling reagent] was added into each well of the 96-well assay plates and the probes were incubated for $2 \mathrm{~h}$ at $37^{\circ} \mathrm{C}$. Absorbance at $490 \mathrm{~nm}$ was measured in a Wallace microplate reader. The MTS reduction values were expressed as a percentage of the control (untreated cells) [30].

\section{Antioxidant enzymes}

SOD activity. The activity of SOD was estimated using Winterbourn method [31], based on the ability of SOD to inhibit the reduction of NBT by superoxide. Briefly, $200 \mu 1$ of samples supernatant were added to $0.1 \mathrm{M}$ EDTA containing $0.3 \mathrm{mM}$ sodium cyanide and $1.5 \mathrm{mM}$ NBT. Then $0.12 \mathrm{mM}$ riboflavin in $0.067 \mathrm{M}$ phosphate buffer, $\mathrm{pH} 7.8$ was added and the samples were incubated at room temperature for $12 \mathrm{~min}$. The absorbance of the samples was recorded using a Gene sys 10 UV spectrophotometer at $560 \mathrm{~nm}$ for $5 \mathrm{~min}$. The activity of SOD was expressed as $\mathrm{mU} / \mathrm{mg}$ protein. 
CAT activity. Catalase activity was determined by measuring the decrease in absorbance at $240 \mathrm{~nm}$ of a reaction mixture consisting of $17 \mu \mathrm{l}$ $\mathrm{H}_{2} \mathrm{O}_{2}$, in $50 \mathrm{mM} \mathrm{K}$ phosphate buffer (5 ml, $\mathrm{pH} 7.0$ ), and incubated in dark condition [32]. After a few minutes $50 \mu \mathrm{l}$ of this solution with $50 \mu \mathrm{l}$ of the cell homogenate added to $900 \mu \mathrm{K}$ K-phosphate buffer $\left(\mathrm{KH}_{2} \mathrm{PO}_{4}, \mathrm{pH}\right.$ 7.0). The CAT activity was expressed as $\mathrm{mU} / \mathrm{mg}$ protein.

Determination of GSH level. The level of glutathione was estimated by Tietz method [33]. Briefly, the samples were first de-proteinized with 5-sulfosalicylic acid solution (5\%) and centrifuged at $10000 \mathrm{rpm}$ for $1 \mathrm{~min}$. The supernatant was used to estimate the amount of GSH. The samples or standards $(10 \mu \mathrm{l})$ were incubated with $150 \mu \mathrm{l}$ of working mixture assay buffer with 5,5'-Dithiobis (2-nitrobenzoic acid) and glutathione reductase (DTNB) in $0.1 \%$ sodium citrate for $5 \mathrm{~min}$. The absorbance of the samples was recorded at $412 \mathrm{~nm}$ using the microplate reader. The results were expressed as $\mathrm{nmol} / \mathrm{mg}$ protein.

Lipid peroxidation assay. The MDA level was determined according to Satoh method [34]. Briefly, plasma was prepared by centrifugation (40000 rpm, $10 \mathrm{~min}$ ) of the whole blood sample collected on TCA. Then, $0.5 \mathrm{ml}$ barbituric acid $67 \%$ was added and boiled in boiling water bath for $30 \mathrm{~min}$. Then, the samples were allowed to cool at room temperature. After addition of $0.5 \mathrm{ml}$ of butanol, the samples were centrifuged at $40000 \mathrm{rpm}$ for $15 \mathrm{~min}$. Light absorption of the upper supernatant was monitored at $532 \mathrm{~nm}$ by ELISA device. MDA concentration was expressed as $\mathrm{pmol} / \mathrm{mg}$ protein.

Western Blot Analysis. Western blot analysis was used to evaluate CB1 Receptor protein level. The cells were lysed by lysis buffer [0.5 M Tris- $\mathrm{HCl}$ (pH 7.4), $150 \mathrm{mM} \mathrm{NaCl}, 0.5 \%$ deoxycholic acid, $1 \%$ Triton X100, and protease inhibitors (1 tablet $/ 50 \mathrm{ml}$ Tris Buffer (pH 7.2), $0.1 \%$ SDS] incubated at $4{ }^{\circ} \mathrm{C}$ for $30 \mathrm{~min}$ and centrifuged (14000 rpm, $\left.4{ }^{\circ} \mathrm{C}, 20 \mathrm{~min}\right)$. Protein concentration was determined by Bradford assay. After that, equal amounts of protein $(50 \mu \mathrm{g})$ were mixed with loading buffer and incubated at $100{ }^{\circ} \mathrm{C}$ for $5 \mathrm{~min}$. The samples were electrophoresed on $12 \%$ density SDS polyacrylamide gels. Then, the protein was transferred to a nitrocellulose membrane $(20 \mathrm{~V})$. Non-specific binding was blocked with $5 \%$ fat-free skim milk in TBST buffer for $2 \mathrm{~h}$ at room temperature. Then, nitrocellulose membrane was incubated with 1 to 200 dilutions of rabbit polyclonal
CB1 antibody (sc-20754, Santa Cruz, USA) in 2.5\% fat-free skim milk and TBS overnight at $4{ }^{\circ} \mathrm{C}$. After washing with TBST, the nitrocellulose membrane was incubated with HRP-conjugated anti-rabbit IgG (1 to 10,000 dilutions) as secondary antibody, for $60 \mathrm{~min}$ at room temperature. Finally, the nitrocellulose membrane was incubated with the $3,3^{\prime}, 5$, $5^{\prime}$ tetramethybenzidine (TMB) liquid substrate system until protein bands appeared [24]. Finally, the Image J software was used for densitometry of the western blot results.

Statistical analysis. The data were expressed as the mean value $\pm \mathrm{SEM}$. All variables were analyzed using one-way analysis of variance (ANOVA) followed by post hoc LSD multiple comparison tests using software obtained from SPSS 20. In some cases, independent sample T-Test were used. Significance level was based on $P<0.05$.

\section{Results and Discussion}

The effects of ACEA and NMDA on PC12 Cells Survival. Exposure of PC12 cells to $100 \mu \mathrm{M}$ POX for $48 \mathrm{~h}$ reduced cell viability by up to $20 \%$ of the untreated cells (control) $(P<0.001)$. We found that application of ACEA (CB1 receptor agonist), NMDA (NMDA receptor agonist) or both agonists increased cell survival vs the POX group $(P<0.001)$ indicating the neuroprotective effect against paraoxon. To determine whether the neuroprotective effect of ACEA was CB1 receptor-mediated, PC12 cells were treated with AM251 for 15 min prior to ACEA addition. The results showed that the neuroprotective effect of ACEA was abolished (Fig. 1, $P<0.05$ ).

The effect of ACEA and NMDA on glutathione level. Incubation of PC12 cells with $100 \mu \mathrm{M}$ POX for $48 \mathrm{~h}$ significantly decreased the level of GSH compared with control group (Fig. $2, P<0.01$ ). We found that application of ACEA $(1 \mu \mathrm{M})$ and NMDA $(100 \mu \mathrm{M})$ led to normalization of GSH level. When ACEA and NMDA were used in combination, the GHS level was increased in comparison with control $(P<0.01)$ but not in comparison with ACEA or NMDA used alone. Administration of CB1 receptor antagonist AM251 before ACEA application caused a significant reduction $(P<0.05)$ of GSH level compared with the group treated with ACEA alone.

The effect of the ACEA and NMDA on superoxide dismutase activity. Incubation of $\mathrm{PC} 12$ cells with $100 \mu \mathrm{M}$ POX for $48 \mathrm{~h}$ significantly decreased (Fig. 3, $P<0.05$ ) the superoxide dismutase activity compared with control group. A significant increase 


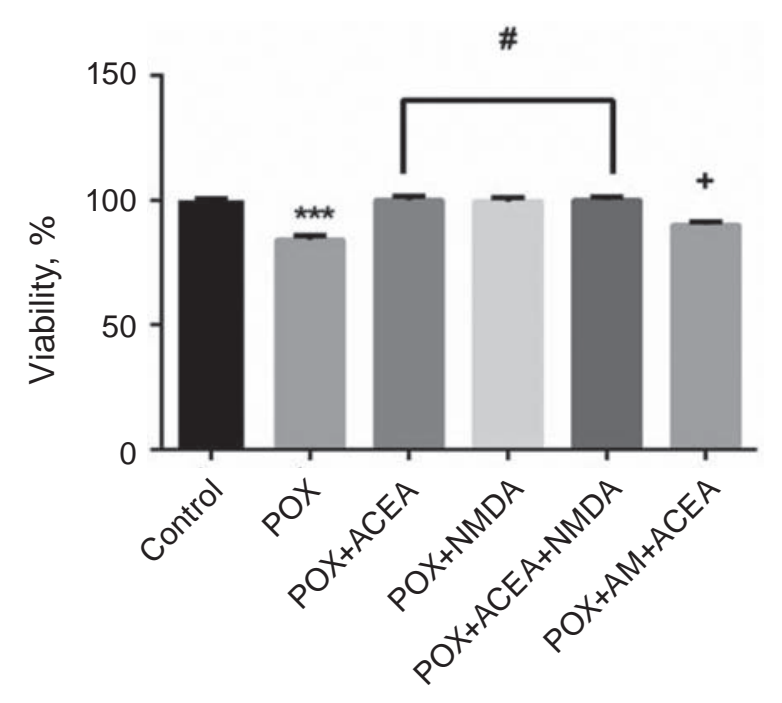

Fig. 1. The effect of ACEA and NMDA on survival of PC12 cells treated with paraoxon. The viability PC12 cells in the control group was taken as $100 \%$. ${ }^{* * *} P<0.001$ compared with control group; $\# P<0.05$ compared with POX group $;+P<0.05$ compared with $P O X+A C E A$ group

$(P<0.05)$ of SOD activity compared with paraoxon group was detected only when ACEA and NMDA were used in combination. This effect was not significantly decreased when CB1 receptor antagonist AM251 was applied.

The effect of ACEA and NMDA on catalase activity. Incubation of PC12 cells with $100 \mu \mathrm{M}$ POX for $48 \mathrm{~h}$ significantly decreased (Fig. $4, P<0.01$ ) the catalase activity compared with control group. Application of ACEA $(1 \mu \mathrm{M})$ and NMDA $(100 \mu \mathrm{M})$ either alone or in combination caused a similar increase $(P<0.05)$ of catalase activity compared with paraoxon group. Application of AM251 before exposure to ACEA resulted in catalase activity reduction $(P<0.05)$ compared with ACEA group.

The effect of ACEA and NMDA on MDA level. Incubation of PC12 cells with $100 \mu \mathrm{M}$ pox for $48 \mathrm{~h}$ significantly increased (Fig. 5, $P<0.01$ ) the level of MDA compared with control group. When ACEA $(1 \mu \mathrm{M})$ and NMDA $(100 \mu \mathrm{M})$ either alone or in combination were applied, the level of MDA came to normal level $(P<0.01)$. Treatment with AM251 before ACEA caused a significant reduction $(P<0.05)$ of the level of MDA compared with ACEA group.

The effect of the ACEA and NMDA on the level of CB1 receptor protein. The level of CB1 receptor protein in PC12 cells treated with POX was decreased compared with control group $(P<0.05)$.

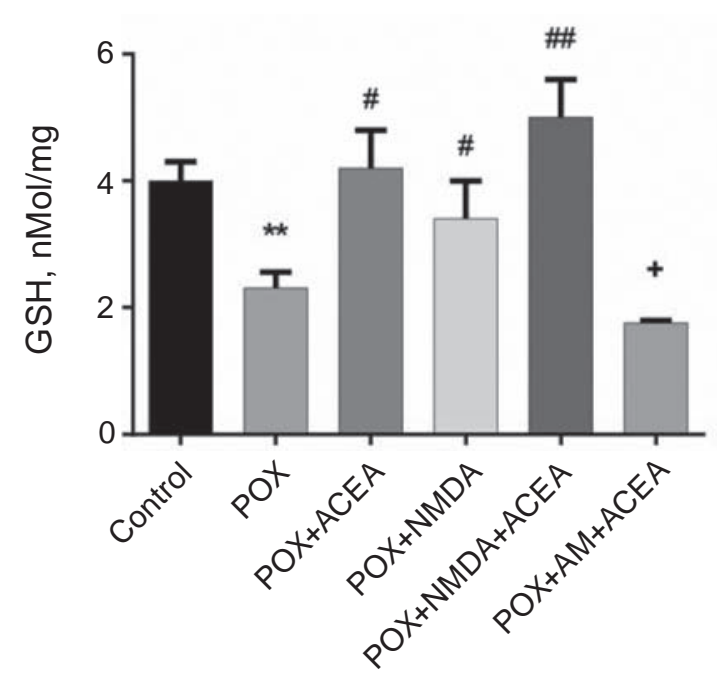

Fig. 2. The effect of ACEA and NMDA on the level of glutathione in PC12 cells treated with paraoxon. ${ }^{* * P}<0.001$ compared with control group; $\# P<0.05$ and \#\#P $<0.01$ compared with $P O X$ group. $+P<0.0001$ compared with $P O X+A C E A$ group

Application of ACEA $(1 \mu \mathrm{M})$ and NMDA $(100 \mu \mathrm{M})$ either alone or in combination caused an increase $(P<0.05)$ of CB1 receptor protein level compared with paraoxon group. When AM251 was applied before exposure to ACEA, the level of CB1 receptor protein was decreased $(P<0.05)$ compared with ACEA group.

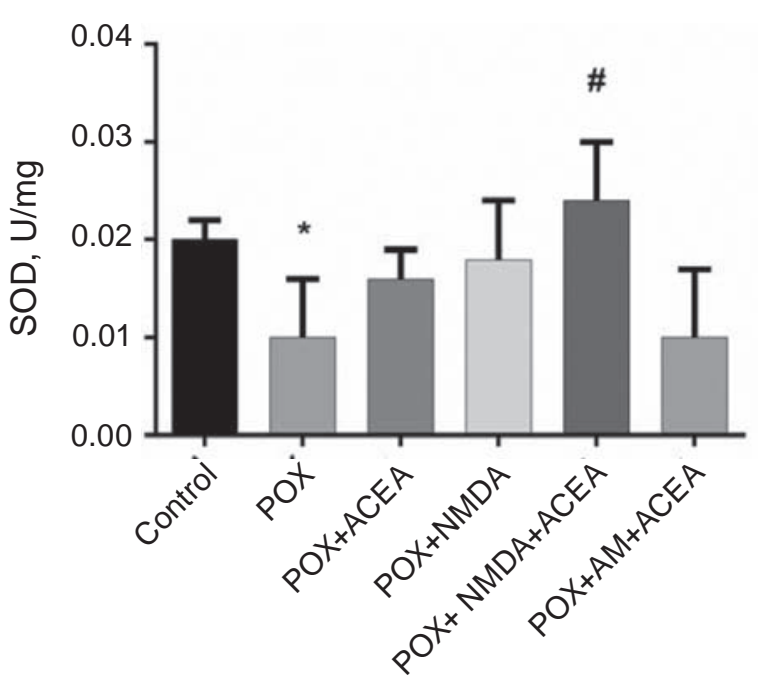

Fig. 3. The effect of ACEA and NMDA on superoxide dismutase activity of PC12 cells treated with paraoxon. ${ }^{*} P<0.05$ compared with control group. $\# P<0.05$ compared with $P O X+A C E A$ group 


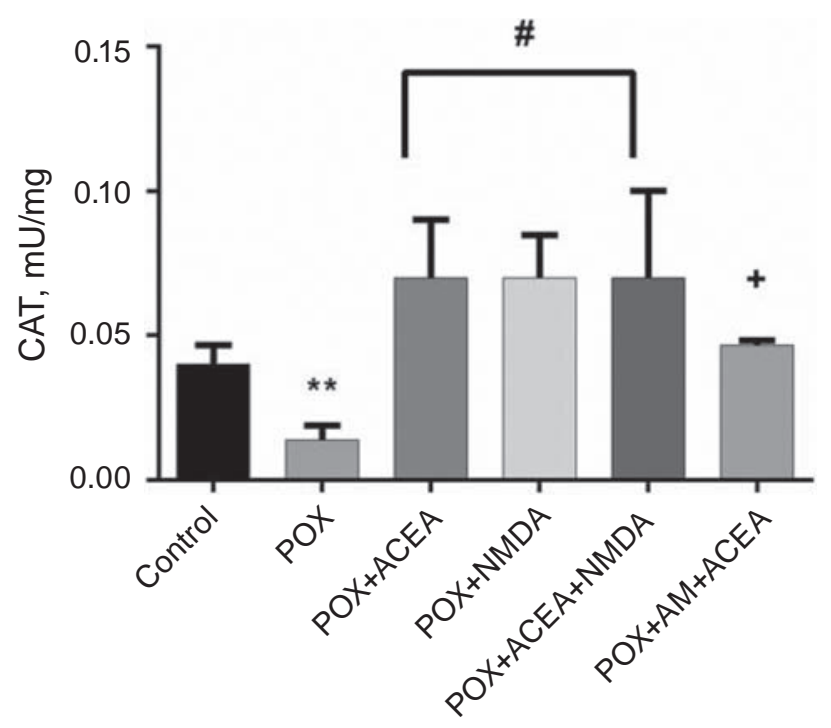

Fig. 4. The effect of ACEA and NMDA on catalase activity in PC12 cells treated with paraoxon. ${ }^{* *} P<0.01$ compared with control group. $\# P<0.05$ compared with POX group. $+P<0.05$ compared with $P O X+A C E A$ group

In the present study we demonstrated that treatment with organophosphorus compound paraoxon decreased the survival of PC12 cells while application of CB1 and NMDA receptors agonists ACEA and NMDA, respectively, protected PC12 cells from POX-induced death. In consistent with current results, we previously found that incubation of PC12 cells with ACEA or NMDA protected PC12 cells from the diazinon organophosphate agent toxic effect [23]. In the current study we observed that CB1 receptor antagonist AM251 suppressed the protective ACEA effect against paraoxon indicating that this effect was partly CB1 receptor-dependent. Several studies on different models of neurotoxicity have shown that CB1 receptors activation is efficient in enhancing cell survival and viability $[3,35]$. Wolf et al. demonstrated that application of Cannabidiol increased adult neurogenesis in female $\mathrm{C} 57 \mathrm{Bl} / 6$ and Nestin-GFP-reporter mice.

There are some investigations that support the interaction of cannabinoid receptors with other neurotransmitters and receptors. Liu, et al., reported that neuroprotective role of glutamate receptors (GluR2) against cerebral ischemia is realized via CB1 receptors [38]. Pazos et al., showed the interaction of CB2 cannabiniod receptors with 5HT1A serotonin receptors in protection from hypoxic-ischemic damage [39].

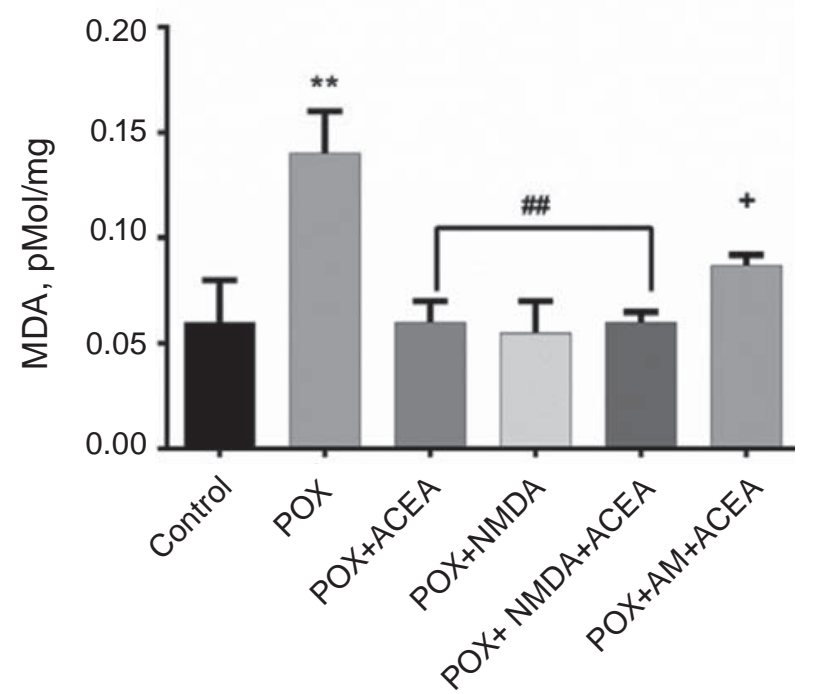

Fig. 5. The effect of ACEA and NMDA on the MDA level in PC12 cells treated with paraoxon. ${ }^{* *} P<0.01$ compared with control group. \#\#P $<0.01$ compared with POX group. $+P<0.05$ compared with $P O X+A C E A$ group

It was reported that survival of many neuronal cell types is dependent on activity of NMDA receptors. Several evidences revealed that blockade of NMDA receptor activity leads to a widespread apoptosis and neurodegeneration in the adult CNS. For example, Ikonomidou et al., have shown that blockade of NMDA receptors for a few hours during late fetal or early neonatal life resulted in apoptotic neurodegeneration in the developing rat brain [36]. The authors suggest that NMDA completely blocks caspase-3 activation responsible for inducing apoptosis and protects almost all vulnerable neurons against POX-induced neuronal cell death. Some researchers reported that NMDA-mediated neuroprotection is provided by different mechanisms, particularly, by regulation of the antioxidant system function [37].

The antioxidant and anti-inflammatory effect of cannabinoids are mentioned in many investigations [40] but oxidative stress as a mechanism of toxicity associated with exposure to organophosphates has been little studied. Some studies have shown the induction of oxidative stress in human salivary gland cells by POX [41].

Therefore, the second task was to estimate variations of antioxidant system activity. In the current study, we demonstrated that application of POX significantly reduced GSH level, CAT and SOD ac- 


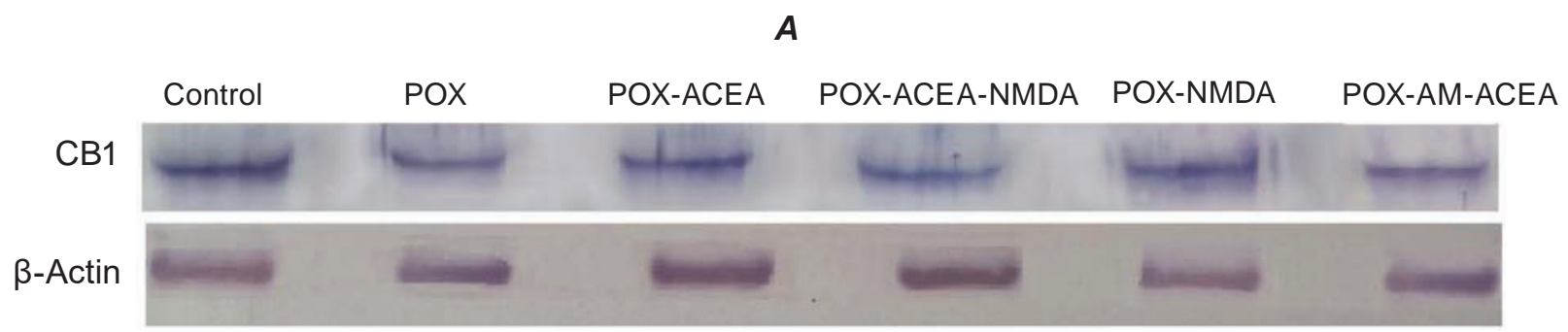

B

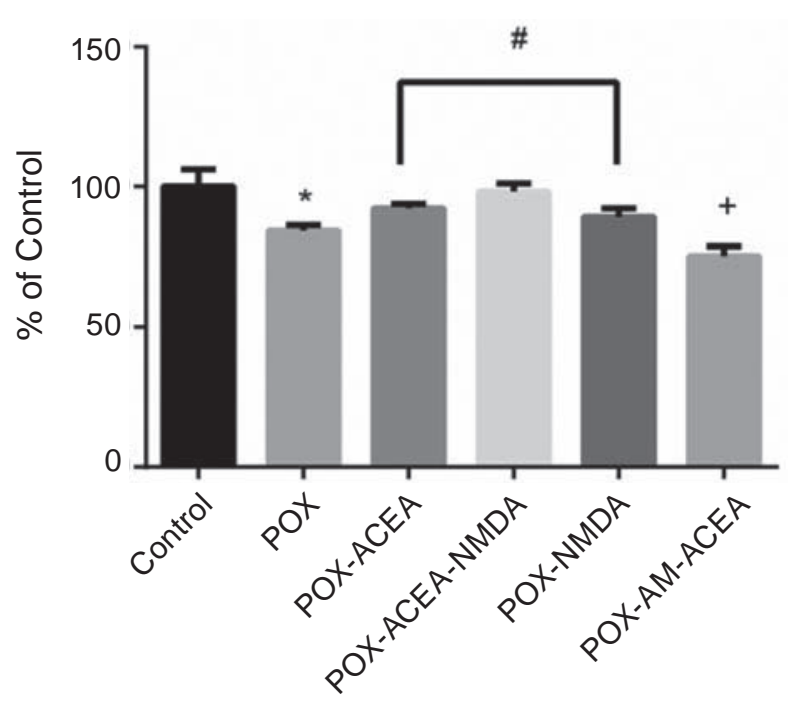

Fig. 6. The effect of ACEA and NMDA on the level of CB1 receptor protein in PC12 cells treated with paraoxon. $\boldsymbol{A}$ - The data of Western blot analysis. $\boldsymbol{B}$ - Quantitative analysis of CB1 receptor protein expression. $* P<0.05$ compared with control group. $\# P<0.05$ compared with POX group. $+P<0.05$ compared with $P O X+$ ACEA group

tivity and increased lipid peroxidation by increasing MDA level in PC12 cells.

Current data suggest that realization of ACEA and NMDA protective effect against POX toxicity could be associated with increasing of GSH level and CAT activity and suppression of lipid peroxidation [41]. We found that the effect of ACEA on GSH level, CAT activity and MDA level was CB1 receptor-dependent, because application of AM251 as ACEA antagonist prevented the antioxidant effect induced by this cannabinoid [42]. The results of SOD activity measurement revealed that cotreatment with ACEA and NMDA was followed by more pronounced recovery of the activity of this enzyme compared with the ACEA or NMDA applied alone and this effect was not $\mathrm{CB} 1$ receptor-dependent, because it was not suppressed by AM251. This data suggest the specific involvement of NMDA receptors in regulation of antoxidant system activity. Our results also showed that simultaneous application of
CB1 and NMDA receptors agonists cannot induce synergistic effect on evaluated parameters in $\mathrm{PC} 12$ cells. Our finding suggests that protective effect of NMDA and ACEA application may be mediated by enhancing of CB1 receptor expression in PC12 cells treated with POX. The role of direct ACEA-dependent CB1 receptor activation in neuroprotection is confirmed by our finding that CB1 receptor antagonist AM251 significantly decreased cell viability and CB1 receptor expression induced by ACEA in PC12 cells treated with POX.

Consistent with these results are our previous studies which have shown that cannabinoid receptor agonist WIN-55,212-2 protects differentiated PC12 cells from organophosphorus- induced apoptosis [43] and that stimulation of CB1 cannabinoid and NMDA receptors increases neuroprotective effect against diazinon-induced neurotoxicity [44].

So, our findings showed that ACEA and NMDA protect PC12 cells against paraoxon-induced toxicity 
possibly through antioxidant capacity increment, lipid peroxidation inhibition and enhanced expression of CB1 receptors.

Acknowledgments. Present study was supported by Neuroscience Research Center, Baqiyatallah University of Medical Sciences. We thank Professor Sahraei for revising the manuscript.

Compliance with Ethics Guidelines. The study is performed according to Helsinki principals of ethics.

Conflict of Interest. Salem F, Bahrami F, Bahari Z, Jangravi Z, declare that they have no conflict of interest.

\section{АГОНІСТИ РЕЦЕПТОРІВ СВ1 I NMDA ЗМЕНШУЮТЬ ТОКСИЧНУ ДІЮ ФОСФОРОРГАНІЧНОЇ СПОЛУКИ ПАРАОКСОН НА КЛІТИНИ РС12}

\section{F. Salem ${ }^{1}$, F. Bahrami ${ }^{1,2 \bowtie}$, Z. Bahari ${ }^{2}$, Z. Jangravi ${ }^{3}$, S. Najafizadeh-Sari ${ }^{4}$}

${ }^{1}$ Neuroscience Research Center, Baqiyatallah University of Medical Sciences, Tehran, Iran;

${ }^{2}$ Department of Physiology and Medical Physics, Faculty of Medicine, Baqiyatallah University of Medical Sciences, Tehran, Iran; ${ }^{3}$ Departmentof Biochemistry, Faculty of Medicine, Baqiyatallah University of Medical Sciences, Tehran, Iran;

${ }^{4}$ Student' Research Committee (SRC), Baqiyatallah University of Medical Sciences, Tehran, Iran; 凶e-mail: f.bahrami@bmsu.ac.ir; farideh_bahrami@yahoo.com

Фармакологічні дослідження дозволяють припустити, що активація канабіноїдних рецепторів типу 1 (CB1) має нейропротекторний ефект щодо індукованих фосфорорганічними агентами порушень, але точних механізмів цього ефекту, а також взаємодію з рецепторами інших типів не з'ясовано. Метою цього дослідження було оцінити вплив агоністів рецепторів CB1 i NMDA на життєздатність клітин і біомаркери окисного стресу та пероксидного окислення ліпідів в клітинах РС12, які зазнали впливу параоксону. На клітини РС12 діяли 100 мкМ параоксону (фосфорорганічий агент). Проводили обробку 1 мкМ арахідоніл-2'-хлоретиламіду (ACEA) (специфічний агоніст рецепторів CB1), 100 мкM N-метил-D-аспартату (NMDA) (агоніст рецепторів NMDA) і 1 мкM AM251 (антагоніст рецепторів CB1). Життєздатність клітин i біомаркери окисного стресу оцінювали через 48 год інкубації. Рівень протеїну рецептора CB1 оцінювали методом Вестерн-блот. Продемонстровано, що обробка клітин PC12 параоксоном призводила до пригнічення життєздатності клітин, зниження рівня глутатіону, зниження активності супероксиддисмутази і каталази, посилення пероксидного окислення ліпідів і ослаблення експресії рецептора CB1. Показано, що застосування ACEA і NMDA нормалізувало ці показники. Протекторний ефект ACEA зникав, коли був застосований антагоніст рецепторів CB1 AM251. Таким чином, застосування ACEA i NMDA може захистити клітини РC12 від токсичної дії параоксону завдяки збільшенню антиоксидантної здатності їх, пригніченню пероксидного окислення ліпідів і посиленню експресії рецепторів CB1.

Кл юч ов і слова: рецептори CB1, арахідоніл-2'-хлоретиламід, канабіноїд, $\mathrm{N}$-метил-D-аспартат, параоксон, клітини PC12, окислювальний стрес.

\section{References}

1. Marsicano G, Lutz B. Neuromodulatory functions of the endocannabinoid system. $J$ Endocrinol Invest. 2006; 29(3 Suppl): 27-46.

2. Shohami E, Cohen-Yeshurun A, Magid L, Algali M, Mechoulam R. Endocannabinoids and traumatic brain injury. Br J Pharmacol. 2011; 163(7): 1402-1410.

3. Chen J, Lee CT, Errico S, Deng X, Cadet JL, Freed WJ. Protective effects of $\operatorname{Delta}(9)$ tetrahydrocannabinol against N-methyl-daspartate-induced AF5 cell death. Brain Res Mol Brain Res. 2005; 134(2): 215-225.

4. Coomber B, O'Donoghue MF, Mason R. Inhibition of endocannabinoid metabolism attenuates enhanced hippocampal neuronal activity induced by kainic acid. Synapse. 2008; 62(10): 746-755.

5. Sinor AD, Irvin SM, Greenberg DA. Endocannabinoids protect cerebral cortical neurons from in vitro ischemia in rats. Neurosci Lett. 2000; 278(3): 157-160.

6. Galve-Roperh I, Aguado T, Rueda D, Velasco G, Guzmán M. Endocannabinoids: a new family of lipid mediators involved in the regulation of neural cell development. Curr Pharm Des. 2006; 12(18): 2319-2325. 
7. Basavarajappa BS, Nixon RA, Arancio O. Endocannabinoid system: emerging role from neurodevelopment to neurodegeneration. Mini Rev Med Chem. 2009; 9(4): 448-462.

8. Bedse G, Romano A, Cianci S, Lavecchia AM, Lorenzo P, Elphick MR, Laferla FM, Vendemiale G, Grillo C, Altieri F, Cassano T, Gaetani S. Altered expression of the CB1 cannabinoid receptor in the triple transgenic mouse model of Alzheimer's disease. J Alzheimers Dis. 2014; 40(3): 701-712.

9. Campbell VA, Gowran A. Alzheimer's disease; taking the edge off with cannabinoids? $\mathrm{Br} J$ Pharmacol. 2007; 152(5): 655-662.

10. Van Laere K, Casteels C, Lunskens S, Goffin K, Grachev ID, Bormans G, Vandenberghe W. Regional changes in type 1 cannabinoid receptor availability in Parkinson's disease in vivo. Neurobiol Aging. 2012; 33(3): 620.e1-8.

11. Walsh S, Mnich K, Mackie K, Gorman AM, Finn DP, Dowd E. Loss of cannabinoid CB1 receptor expression in the 6-hydroxydopamineinduced nigrostriatal terminal lesion model of Parkinson's disease in the rat. Brain Res Bull. 2010; 81(6): 543-548.

12. Iuvone T, Esposito G, Esposito R, Santamaria R, Di Rosa M, Izzo AA. Neuroprotective effect of cannabidiol, a non-psychoactive component from Cannabis sativa, on beta-amyloid-induced toxicity in PC12 cells. J Neurochem. 2004; 89(1): 134-141.

13. McAllister SD, Chan C, Taft RJ, Luu T, Abood ME, Moore DH, Aldape K, Yount G. Cannabinoids selectively inhibit proliferation and induce death of cultured human glioblastoma multiforme cells. J Neurooncol. 2005; 74(1): 3140.

14. Hillion JA, Takahashi K, Maric D, Ruetzler C, Barker JL, Hallenbeck JM. Development of an ischemic tolerance model in a PC12 cell line. J Cereb Blood Flow Metab. 2005; 25(2): 154162.

15. Vaudry D, Stork PJ, Lazarovici P, Eiden LE. Signaling pathways for $\mathrm{PC} 12$ cell differentiation: making the right connections. Science. 2002; 296(5573): 1648-1649.

16. Garzón J, de la Torre-Madrid E, RodríguezMuñoz M, Vicente-Sánchez A, SánchezBlázquez $\mathrm{P}$. $\mathrm{Gz}$ mediates the long-lasting desensitization of brain CB1 receptors and is essential for cross-tolerance with morphine. Mol Pain. 2009; 5: 11.

17. Sánchez-Blázquez $P$, Rodríguez-Muñoz $\mathrm{M}$, Vicente-Sánchez A, Garzón J. Cannabinoid receptors couple to NMDA receptors to reduce the production of $\mathrm{NO}$ and the mobilization of zinc induced by glutamate. Antioxid Redox Signal. 2013; 19(15): 1766-1782.

18. Marchalant Y, Cerbai F, Brothers HM, Wenk GL. Cannabinoid receptor stimulation is antiinflammatory and improves memory in old rats. Neurobiol Aging. 2008; 29(12): 1894-1901.

19. Salio C, Fischer J, Franzoni MF, Conrath M. Pre- and postsynaptic localizations of the CB1 cannabinoid receptor in the dorsal horn of the rat spinal cord. Neuroscience. 2002; 110(4): 755764.

20. Köfalvi A, Rodrigues RJ, Ledent C, Mackie K, Vizi ES, Cunha RA, Sperlágh B. Involvement of cannabinoid receptors in the regulation of neurotransmitter release in the rodent striatum: a combined immunochemical and pharmacological analysis. J Neurosci. 2005; 25(11): 2874-2884.

21. Rodriguez JJ, Mackie K, Pickel VM. Ultrastructural localization of the CB1 cannabinoid receptor in mu-opioid receptor patches of the rat Caudate putamen nucleus. J Neurosci. 2001; 21(3): 823-833.

22. Chakraborty A, Murphy S, Coleman N. The Role of NMDA Receptors in Neural Stem Cell Proliferation and Differentiation. Stem Cells Dev. 2017;26(11):798-807.

23. Nacher J, McEwen BS. The role of N-methylD-asparate receptors in neurogenesis. Hippocampus. 2006; 16(3): 267-270.

24. Wu X, Tian F, Okagaki P, Marini AM. Inhibition of N-methyl-D-aspartate receptors increases paraoxon-induced apoptosis in cultured neurons. Toxicol Appl Pharmacol. 2005; 208(1): 57-67.

25. Forrest D, Yuzaki M, Soares HD, Ng L, Luk DC, Sheng M, Stewart CL, Morgan JI, Connor JA, Curran T. Targeted disruption of NMDA receptor 1 gene abolishes NMDA response and results in neonatal death. Neuron. 1994; 13(2): 325-338.

26. Tashiro A, Sandler VM, Toni N, Zhao C, Gage FH. NMDA-receptor-mediated, cellspecific integration of new neurons in adult dentate gyrus. Nature. 2006; 442(7105): 929933. 
27. Girón-Pérez MI, Santerre A, Gonzalez-Jaime F, Casas-Solis J, Hernández-Coronado $\mathrm{M}$, Peregrina-Sandoval J, Takemura A, Zaitseva G. Immunotoxicity and hepatic function evaluation in Nile tilapia (Oreochromis niloticus) exposed to diazinon. Fish Shellfish Immunol. 2007; 23(4): 760-769.

28. Abdou HM, ElMazoudy RH. Oxidative damage, hyperlipidemia and histological alterations of cardiac and skeletal muscles induced by different doses of diazinon in female rats. J Hazard Mater. 2010; 182(1-3): 273-278.

29. Kaur R, Sandhu HS. In vivo changes in antioxidant system and protective role of selenium in chlorpyrifos-induced subchronic toxicity in bubalus bubalis. Environ Toxicol Pharmacol. 2008; 26(1): 45-48.

30. Hashemi M, Bahrami F, Sahraei H, Golmanesh L, Sadri S. The neuroprotective effect of cannabinoid receptor agonist (WIN55,212-2) in paraoxon induced neurotoxicity in PC12 cells and $\mathrm{N}$-methyl-D-aspartate receptor interaction. Yakhteh Med J. 2010; 12(2): 183-190.

31. Winterbourn CC, Hawkins RE, Brian M, Carrell RW. The estimation of red cell superoxide dismutase activity. $J$ Lab Clin Med. 1975;85(2): 337-341.

32. Aebi H. Catalase in vitro. Methods Enzymol. 1984; 105: 121-126.

33. Tietze F. Enzymic method for quantitative determination of nanogram amounts of total and oxidized glutathione: applications to mammalian blood and other tissues. Anal Biochem. 1969; 27(3): 502-22.

34. Satoh K. Serum lipid peroxide in cerebrovascular disorders determined by a new colorimetric method. Clin Chim Acta. 1978; 90(1): 37-43.

35. Wolf SA, Bick-Sander A, Fabel K, LealGalicia P, Tauber S, Ramirez-Rodriguez G, Müller A, Melnik A, Waltinger TP, Ullrich O, Kempermann G. Cannabinoid receptor CB1 mediates baseline and activity-induced survival of new neurons in adult hippocampal neurogenesis. Cell Commun Signal. 2010; 8: 12.

36. Ikonomidou C, Bosch F, Miksa M, Bittigau P, Vöckler J, Dikranian K, Tenkova TI, Stefovska V, Turski L, Olney JW. Blockade of NMDA receptors and apoptotic neurodegeneration in the developing brain. Science. 1999; 283(5398): 70-74.

37. Lipton SA. NMDA receptor activity regulates transcription of antioxidant pathways. Nat Neurosci. 2008; 11(4): 381-382.

38. Liu Z, Chen X, Gao Y, Sun S, Yang L, Yang Q, Bai F, Xiong L, Wang Q. Involvement of GluR2 up-regulation in neuroprotection by electroacupuncture pretreatment via cannabinoid CB1 receptor in mice. Sci Rep. 2015; 5: 9490.

39. Pazos MR, Mohammed N, Lafuente H, Santos M, Martínez-Pinilla E, Moreno E, Valdizan E, Romero J, Pazos A, Franco R, Hillard CJ, Alvarez FJ, Martínez-Orgado J. Mechanisms of cannabidiol neuroprotection in hypoxicischemic newborn pigs: role of $5 \mathrm{HT}(1 \mathrm{~A})$ and CB2 receptors. Neuropharmacology. 2013; 71: 282-291.

40. Rajan TS, Giacoppo S, Iori R, De Nicola GR, Grassi G, Pollastro F, Bramanti P, Mazzon E. Anti-inflammatory and antioxidant effects of a combination of cannabidiol and moringin in LPS-stimulated macrophages. Fitoterapia. 2016; 112: 104-115.

41. Prins JM, Chao CK, Jacobson SM, Thompson CM, George KM. Oxidative stress resulting from exposure of a human salivary gland cells to paraoxon: an in vitro model for organophosphate oral exposure. Toxicol In Vitro. 2014; 28(5): 715-721.

42. Contino M, Capparelli E, Colabufo NA, Bush AI. Editorial: The CB2 Cannabinoid System: A New Strategy in Neurodegenerative Disorder and Neuroinflammation. Front Neurosci. 2017; 11: 196.

43. Sadri S, Bahrami F, Khazaei M, Hashemi M, Asgari A. Cannabinoid receptor agonist WIN55,212-2 protects differentiated PC12 cells from organophosphorus- induced apoptosis. Int $J$ Toxicol. 2010; 29(2): 201-208.

44. Bahrami F, Hashemi M, Khalili F, Hashemi J, Asgari A. Stimulation of CB1 Cannabinoid and NMDA Receptors Increases Neuroprotective Effect against Diazinon-Induced Neurotoxicity. Neurophysiology. 2013; 45(5-6): 433-440. 